\title{
SOME ASPECTS OF THE COMMERCIAL TREATY PROGRAM OF THE UNITED STATES- PAST AND PRESENT
}

\author{
Austin T. Foster*
}

\section{INTRODUCTION}

In the "Proposals for Expansion of World Trade and Employment," issued by the State Department in connection with the announcement of the recently negotiated loan to Great Britain, the United States has served notice of intention to continue its policy of working toward the elimination of barriers to the flow of international commerce. Great Britain has stated that it "is in full agreement on all important points in these Proposals and accepts them as a basis for international discussion." Since nationals of Great Britain and of the United States carry on a large proportion of the aggregate world trade, their agreement to cooperate in an endeavor to obtain relaxation of restrictions of various kinds on world trade is highly important.

The Proposals contemplate a program of international agreements or treaties which might be entered into either on a multilateral or on a bilateral basis, and which will progressively open the channels of trade between nations. The program provides for an amplification of the Reciprocal Trade Agreements program initiated by former Secretary of State Cordell Hull and, as evidence of the intention of the United States to retain leadership in the program, invitations have been issued to fourteen countries ${ }^{3}$ to negotiate reciprocal trade agreements or revisions of existing agreements of this character prior to the conference to be called for the purpose of organizing the International Trade Organization. The intrinsic soundness of the Proposals, their endorsement by the two principal trading nations of the world and the promptness of the United States in taking the first steps to implement them make it reasonable to hope for a very substantial measure of success for the program contemplated.

In Chapter VI, Section A of the Proposals for Expansion of World Trade and

-A.B., 1914, LL.B., 1917, Harvard University. Member of the New York Bar. Counsel, SoconyVacuum Oil Company, Incorporated. Chairman, Sub-Committee on Treaties of the Law Committee of the National Foreign Trade Council. Member of the American Society of International Law and of the American Bar Association (Section on International and Comparative Law).

I Dep't of State, Proposals for Expansion of World Trade and Emploxment (Publication 24II, Commercial Policy Series 79, 1945).

${ }^{2}$ Dep't of State, Press Release, Dec. 6, 1945 , quoted in Journal of Commerce and Commercial (New York), Dec. 7, 1945.

${ }^{3}$ New York Times, Dec. 14, 1945, p. I, col. r. 
Employment, the importance of international agreements other than reciprocal trade agreements is recognized in that one of the proposed functions of the International Trade Organization is "(6) To make recommendations for international agreements designed to improve the bases of trade and to assure just and equitable treatment for the enterprises, skills and capital brought from one country to another, including agreements on the treatment of commercial travelers, on commercial arbitration, and on the avoidance of double taxation." International agreements covering these subjects, in so far as they have heretofore been dealt with in comprehensive treaties to which the United States is a party, fall traditionally within the general scope of (a) treaties of friendship, commerce and navigation, (b) treaties for the protection of industrial property, including patents, trade-marks and copyrights, and (c) treaties for the avoidance of double taxation. The United States, although its nationals have taken an important part in the development of commercial arbitration, is not itself a party to any international agreement dealing with the subject.

Adoption on a broad multilateral basis of international agreements for the purposes specified in Chapter VI, Section A, of the Proposals appears to be an integral part of the program of the International Trade Organization. In the following pages it is pointed out that there are many countries with which the United States does not have comprehensive treaties of friendship, commerce and navigation; that the commercial treaties and agreements to which the United States is a party (except reciprocal trade agreements) were, to a considerable extent, entered into before the development of international trade in its modern form and are, therefore, inadequate; that in the years immediately preceding World War II and during that war various factors, including government control over and participation in international trade, went far to change the character of commercial relations between nations; and that the failure to enter into comprehensive commercial treaties of various types, particularly treaties of friendship, commerce and navigation supplementing those reciprocal trade agreements the negotiation of which is now contemplated, may affect adversely our efforts to further the relaxation of trade barriers aimed at in the Proposals.

\section{Brief Historical Sketch}

The present time seems a natural one for a review of our entire system of commercial treaties. After the end of the Napoleonic Wars in 1815, President Monroe, in" a letter, stated that "the Treaties between the United States and some of the Powers of Europe having been annulled by causes proceeding from the state of Europe for some time past and other treaties having expired the United States have now to form their system of commercial intercourse with every Power as it were at the same time." This statement is largely applicable today.

The foreign commercial policy of the United States of recent years has had as its avowed purpose 'equality' of opportunity through non-discriminatory multilateral

\footnotetext{
'DEP'T of STATE, op. cit. supra note $I$, at 24.

- Hasweli, Treaties and Conventrons (Concluded Between the United States of America and Other Powers, 1889) 1224, quoting from M. S. Department of State.
} 
trade relations for American private enterprise. The seed of this policy appears to have been sown in the early days of the American Revolution. On September $\mathrm{x} 7$, 1775, the Continental Congress, before sending to Paris a Mission to negotiate a treaty with France, adopted a plan for the treaty, Article II of which is worth quoting:

\section{"Article II}

The subjects, people and inhabitants of the said United States, and every of them, shall pay no other duties, or imposts, in the ports, havens, roads, countries, islands, cities or towns of the most christian king, than the natives of such countries, islands, cities or towns of France, or any commercial companies established by the most christian king, shall pay, but shall enjoy all other the rights, liberties, privileges, immunities and exemptions in trade, navigation and commerce, in passing from one port thereof to another, and in going to and from the same, from and to any part of the world, which the said natives or companies enjoy."

The suggestion that the citizens of one country should be entitled within the territory of another to the same treatment as the natives thereof (commonly called "national treatment") was in the eighteenth century somewhat radical. It is, therefore, not surprising that France was unwilling to concede "national treatment" on the broad basis proposed and that, although the Treaty of $177^{7}$ otherwise incorporated almost verbatim the language of Article II as approved by the Continental Congress, "most-favored-nation treatment" was substituted for "national treatment."

Treaties entered into in the early days of the Republic, besides granting the rights stipulated in the French Treaty of 1778 referred to above, prohibited the exaction by the government of either country of the Droit d'Aubaine (escheat of property rights of deceased aliens) and permitted nationals of each country within the territory of the other to hold personal property and to acquire personal property by inheritance. ${ }^{8}$ Real estate in one country could be inherited by a national of the other country but must be promptly sold. In the Treaty of 1815 with Great Britain, it was provided for the first time that no higher charges should be imposed in any of the ports of either country on vessels of the other than were imposed on its own vessels. ${ }^{9}$ The titles of these early treaties refer to "peace" or "amity," but the emphasis in their provisions on the rights of nationals of each country in the event either should be at war with a third country and in the event of war between the two contracting countries evidences the fact that in that era war was a not abnormal condition.

In the Treaty of 1825 with Central America, the parties agreed that commodities which could be imported into either country in its own vessels might be so imported in vessels of the other country. ${ }^{10}$ Trade-marks were first dealt with in a Treaty of

- 2 Secret Journals of the Acts and Proceedings of Congress (1821) 6.

${ }^{7}$ I Treaties (Malloy) 468 (Sen. Doc. 357, 6rst Cong. 2d Sess. I9io).

${ }^{8}$ France (1778), ibid.; Netherlands (1782) 2 Treaties (Malloy) 1233; Sweden (1783), id. at 1725; Prussia (1785), id. at 1477 .

${ }^{\circ}$ i Treaties (Mallox) 624, Article II, page 625.

${ }^{20} \mathrm{Id}$. at 160 . 
I868 with Russia. ${ }^{11}$ In I887 the United States acceded to the 1883 International Convention for the Protection of Industrial Property. ${ }^{12}$ In I904 the United States and Russia each agreed to recognize the legal existence of corporations organized under the laws of the other country and to permit such corporations to appear in its courts. $^{13}$ In IgI9 the United States entered into a series of arrangements with foreign countries dealing with the right of traveling salesmen of one country to travel in the territory of the other. ${ }^{14}$ A series of bilateral arrangements between the United States and various foreign countries was negotiated in Ig2r and subsequent years providing for the reciprocal exemption of nationals of each signatory from income tax in the other imposed on shipping profits. ${ }^{15}$ The first treaty for the avoidance of double taxation on a more comprehensive basis was the Treaty with France signed in 1932 and effective in $1936^{16}$

The Reciprocal Trade Agreements Act was approved on June 12, $1934{ }^{17}$ It authorized the President "to proclaim such modifications of existing duties and other import restrictions . . . as are required or appropriate to carry out any foreign trade agreement that the President has entered into hereunder." The term "duties and other import restrictions" includes "(I) rate and form of import duties and classification of articles and (2) limitations prohibitions charges and exactions other than duties, imposed on importation or imposed for the regulation of imports." It was provided that "no proclamation shall be made increasing or decreasing by more than 50 per cent any existing rate of duty or transferring any article between the dutiable and free list."

It will be noted that the concessions which the United States is authorized to make in reciprocal trade agreements are limited to the modification of duties and other import restrictions. Within the purview of these agreements fall provisions dealing with duties and other taxes and with quantitative restrictions on imports, provisions specifying non-discriminatory treatment in respect of 'exchange control and provisions dealing with government or government-monopoly purchases. They do not and probably cannot deal with many of the matters traditionally dealt with in treaties of friendship, commerce and navigation, such as the right of nationals of one country to do business within the territory of the other; the right of nationals of one country to hold and dispose of property in the territory of the other and to be

112 Treaties (Malloy) 1524 .

${ }^{12} \mathrm{Id}$. at $\mathrm{x} 935$.

${ }^{13}$ Id. at 1534 .

${ }^{14}$ Guatemala (1919) 4I StaT. (pt. 2) 1669, Treaty Series 642; Panama (rgrg) 4r StaT. (pt. 2) r696. Treaty Series 646; Uruguay (1919) 4I STAT. (pt. 2) r663, Treaty Series 640.

${ }^{25}$ Canada (signed 1928, effective for $\mathrm{x} 92 \mathrm{I}$ and subsequent years) 47 STAT. (pt. 2) 2580, Exccutive Agreement Series 4; Denmark and Iceland (1922) 47 STat. (pt. 2) 26r2, Executive Agrecment Series r4; France (1927) 47 STat. (pt. 2) 2604, Executive Agreement Series I2; Great Britain (signed 1924 and 1925, effective as from January I, I921) 47 STAT. (pt. 2) 2587, Executive Agreement Scries 7; Netherlands (signed 1926, effective as from January 1, 1921) 47 STaT. (pt. 2) 2601, Executive Agrecment Series II; Spain (signed r930, effective as from January I, r921) 47 STAт. (pt. 2) 2584, Executive Agreement Series 6.

${ }_{16}^{16} 49$ Star. (pt. 2) $3 \times 45$, Treaty Series 885.

${ }^{17} 48$ STAT. 943 , 19 U. S. C. (1940 ed.) §I 351. 
compensated in the event of its expropriation; and rights of navigation. Neither do these agreements deal with taxes, except those imposed on imports and exports.

The first reciprocal trade agreement became effective in 1934 (Cuba) ${ }^{18}$ and prior to December $3 \mathrm{I}$, I94I, agreements of the same character with twenty-two countries ${ }^{19}$ had been signed and become effective. In the same period (r934 to r94I) three broad treaties of friendship, commerce and navigation (Finland I934, ${ }^{20}$, Siam 1938, ${ }^{21}$ and Liberia $1939^{22}$ ) had gone into effect and two comprehensive treaties for the avoidance of double taxation, including the 1936 Treaty with France ${ }^{23}$ and a Treaty with Sweden (I940)..$^{24}$ Other commercial treaties and agreements which became effective in this period include a number of agreements on specialized subjects, such as aviation, fisheries, exchange control, navigation, and taxation on shipping profits. Sixty-seven such other treaties and agreements in the economic field finalized in this period were in effect on December $3 \mathrm{I}$, $194 \mathrm{I}$.

The last published treaty of friendship, commerce and navigation to which the United States is a party is the Treaty with Liberia referred to above. Subsequent preparation in the Department of State for treaties with other countries of the same nature, the negotiation of which is now planned or may already be under way, has presumably resulted in important changes in form and substance in respect of such contemplated treaties. As no information is given to the public as to the contents of a treaty until after it has been executed and submitted to the Senate for ratification, the nature of these changes is not now known.

There appears on the following page a table showing the treaties and agreements in the commercial field of a more or less comprehensive nature in effect on December $3 \mathrm{I}$, I94I, between the United States and thirty other countries. ${ }^{25}$ Limitations of space made it impracticable to show the less comprehensive treaties and arrangements.

In general, it may be stated that in the nineteenth century and until the passage of the Reciprocal Trade Agreements Act in r934, attempts in the United States to remove or reduce trade barriers through reductions of customs duties met with little success. As a nation the United States insisted on its right to maintain high protective tariffs. Accordingly, the efforts of our government to encourage international trade were largely limited to the making of reciprocal arrangements which contemplated most-favored-nation treatment as to customs duties and other import restrictions, as well as treaties and agreements which required, within the territory of each country, respect for the property and rights of nationals of the other signatory country, and which provided for the reduction of burdens other than customs duties.

${ }^{28} 40$ Srat. (pt. 2) 3559, Executive Agreement Series 67.

${ }^{10}$ Cuba, Belgium, Haiti, Sweden, Canada, Brazil, Netherlands, Switzerland, Honduras, Colombia, Guatemala, France, Nicaragua, Finland, El Salvador, Costa Rica, Czechoslovakia, Ecuador, United Kingdom, Turkey, Venezuela, Argentina: "Announcements under the Reciprocal Trade Agreements Act," Foreign Commerce WeERLY (Feb. I6, r946) 49.

${ }^{30} 49$ STAr. (pt. 2) 2659 , Treaty Series 868 .

8254 STAT. (pt. 2) 1739. Treaty Series 956.

2454 STAT. (pt. 2) r759, Treaty Series 958.

${ }^{21} 53$ STAT. (pt. 3) I731, Treaty Series 940.

${ }_{23} 49$ Stat. (pt. 2) 3I45, Treaty Series 885 .

35 This table was prepared from Dep't of State, Treaties in Fonce (A List of Treaties and Other International Acts of the United States in Force on December 3I, 1941) Publication No. 2103, I944. 
Certain Treaties and Agreemennts in the Commercial Field in Effect on December 3I, I94I, Between the Uínited States and Thirty Foreign Countries

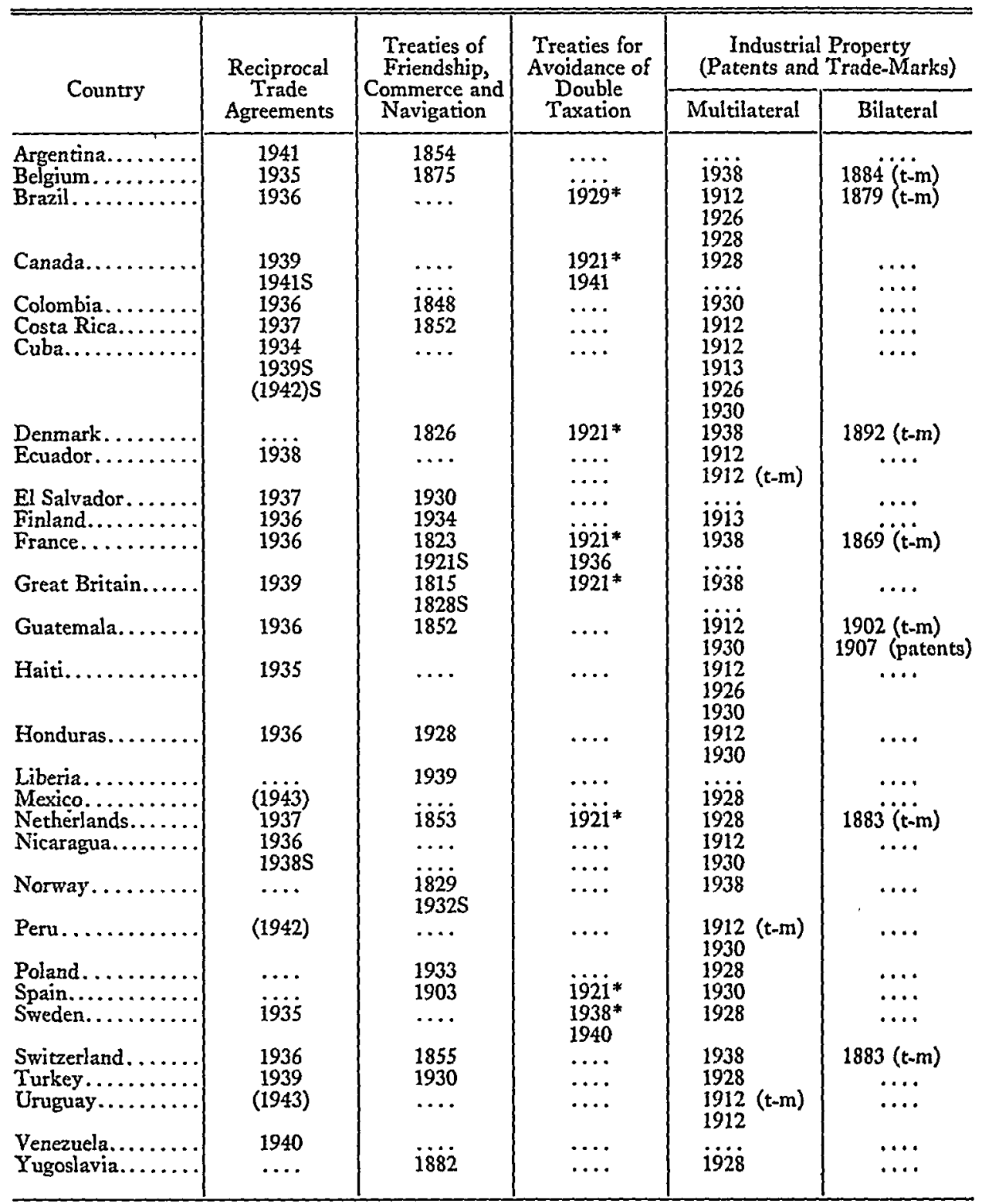

(t-m) - trade-marks.

- applies to shipping profits only.

(1942), (1943) - treaties became effective subsequent to December 31, 1941.

NOTE: Date indicates the year in which the treaty or agreement became effective.

The passage of the Reciprocal 'Trade Agreements Act indicated, and was caused by, growing consciousness in the United States that our imports must be increased if our exports were to be expanded, and that no such increase of imports or exports 
would be possible without reduced customs duties. With the passage of this Act, our policy as to the encouragement of international trade shifted and we proceeded, under the Act, to negotiate reciprocal reductions in customs duties on a substantial scale. The Reciprocal Trade Agreements program is consistent with the free enterprise system and, until the commencement of World War II, our nationals continued their operations in international commerce under that system. Their belief in the adequacy of the free enterprise system is well stated in the Declaration of Principles adopted by the National Foreign Trade Convention in November, I945. Principle XVII is as follows:

"Our foreign trade, like our domestic trade, can best be carried on under a system of free, private, competitive enterprise within a framework of government law and treaty designed to give it encouragement and support. The intervention of the American government in the regulation of foreign trade-as, for example, in the imposition of tariffs, the conservation of natural resources and the prevention of abuses arising from American participation in private international agreements-can have its only justification in the service of the national interest, as distinct from any sectional interest or the interest of any individual industry. The actual entry of the government into foreign trade activity, including the extension of the loans and credits and participation in international commodity agreements, is admissible only in time of war or other international emergency, or when considerations of national policy in the political or economic sphere outweigh the advantages of private trade and the freedom of the market place."26

\section{Analysis of Commercial Treaty Coverage}

The foregoing can give only an inadequate bird's-eye view of the development of the treaty program of the United States from its birth as a nation to the commencement of World War II. It may, however, serve as background for an inquiry as to the subjects covered by commercial treaties and agreements heretofore entered into. The following are some of the subjects of a general nature which have importance to commercial enterprises in times of peace and which are dealt with in existing treaties and international agreements of the United States:

r. Rights of establishment of nationals of one country in the territory of the other

(a) to enter, reside and travel

(b) to carry on trade or business

(c) to appoint agents of one's choice

(d) to rent premises

(e) to have access to the courts.

(f) to introduce commercial travelers and samples

(g) relating to recognition of corporations

2. Rights of navigation of vessels of one country in the territorial waters of the other

(a) to enter the ports

(b) to receive non-discriminatory treatment as to port dues, etc.

(c) to import and export commodities produced in either country

${ }^{20}$ Nat'l For. Trade Council, Final Declaration of the Thirty-Second Nattonal Foreign Trade Convention (New York, November 12, I3, I4, 1945). 
3. Rights of the nationals of one country in respect of real and personal property in the territory of the other

(a) to acquire, hold and dispose of real and personal property

(b) to receive due compensation for property seized or expropriated

4. Rights of the nationals of one country to intangible property rights in the territory of the other

(a) relating to patents, industrial designs, etc.

(b) relating to trade-marks, commercial names, etc.

(c) relating to copyrights, literary property, etc.

5. Rights relating to the products of one country introduced into the territory of the other

(a) to specified rates of duties

(b) to non-discriminatory treatment as to duties

(c) to specified import quotas

(d) to non-discriminatory treatment as to import quotas

(e) to freedom from burdens when in transit

(f) to non-discriminatory treatment in respect of taxes and burdens after importation

(g) to non-discriminatory treatment in respect of purchases by the government or a government monopoly

6. Rights of the nationals of one country as to foreign exchange regulations

(a) to non-discriminatory treatment

7. Rights of the nationals of one country in respect of taxation by the other country

(a) to non-discriminatory treatment as to taxation

(b) to avoidance of double taxation

(c) to exemption from income taxation on international shipping profits.

In so far as these various subjects are covered by comprehensive treaties and agreements, generally speaking those under headings 1,2 , and 3 are dealt with in treaties of friendship, commerce and navigation, those under heading 4 in multilateral conventions, those under headings 5 and 6 in reciprocal trade agreements, and those under heading 7 in treaties for the avoidance of double taxation. In some cases, however, special agreements cover a particular subject (e.g., a number of conventions dealing with commercial travelers and samples in 1919$) ;{ }^{27}$ certain provisions are to be found interchangeably in comprehensive treaties or agreements of various type, e.g., exchange control provisions in Treaty with Liberia (1939) ${ }^{28}$ and in Reciprocal Trade Agreement with Mexico (1942). ${ }^{29}$ Probably there is no country with which the United States has treaties and agreements covering all of the subjects listed above and the form and effectiveness of a provision dealing with any one of these subjects will vary greatly with the date of the treaty and the circumstances under which it was negotiated.

"s Supra, note 14 .

20 Executive Agreement Series 3 II. 


\section{Inadequacies in Light of Changed Conditions}

From the table on page $65_{2}$ of treaties and agreements effective on December $3^{\mathrm{r}}$, 194r, it will be seen that, of the thirty countries listed, there were on that date ten with which no treaty of friendship, commerce and navigation was then effective and ten with which the existing treaty of friendship, commerce and navigation antedates the commencement of the present century. Our earlier treaties make no mention of corporations. Obviously, those which became effective before the inauguration of income tax, exchange control, and government monopoly operation provide no specific coverage in respect of these matters. It is self-evident that treaties drafted in the last century could not cover adequately the complicated commercial relationships between nations as they existed prior to World War II. It may not be out of place, however, to point out some of the basic changes in the position of the United States in international trade and in national policies of foreign countries which emphasize the inadequacy of nineteenth-century treaties on the basis of pre-World-War-II conditions.

In the first place, the nature of commercial relations between countries, and particularly between the United States and foreign nations, has changed. In an earlier period our trade with foreign countries was considered as consisting of the shipment of commodities from a point of export in one country to a point of import in another country. But in fact international commerce no longer always commences at the boundary of the country of origin, nor does it terminate at the boundary of the country of destination. It usually commences at some point of production within the country of origin and, after crossing the boundary of that country and the boundary of the country of destination, enters the channels of domestic commerce within the latter country.

Just as there has been vertical integration of production, manufacture, transportation and distribution within exclusive fields of domestic commerce, so has there been a similar vertical integration involving both domestic and foreign commerce. Production and transportation in the country of origin of goods to be exported and distribution and marketing in the country of destination of imported goods have normally become essential operations in connection with international trade in the goods involved. Restrictions imposed upon or discriminations practised against an American enterprise in domestic business in a foreign country may result in obstructing the international trade carried on by that enterprise as effectively as a direct burden on international trade, such as exorbitant customs duties. Conversely, the elimination of high customs duties may not serve to clear the channels of international trade if there remain such obstructions in the domestic trade within one of the countries involved.

Since the beginning of the present century the commercial enterprises of the United States have expanded their direct investments abroad until before the war it was estimated that they held some $\$ 7,000,000,000$ of direct investments in other 
countries. ${ }^{30}$ American direct investments in Latin America as a whole in 1940 were estimated at around $\$ 2,800,000,000 .{ }^{31}$

By and large, these direct investments of American enterprises are essential to the foreign commerce of the United States. They include oil fields, mines and other facilities for the production of raw materials destined for importation into the United States or for shipment into other foreign countries. They also include distributing facilities for goods exported from the United States and all that goes with integrated enterprises for the marketing abroad of American products. An American exporter begins, for example, exporting gadgets to Morocco and selling them to a local importer, who may also deal in many other commodities. The American concern becomes aware that the importer is not making any great effort to develop consumer demand for these gadgets, and therefore qualifies a branch or organizes a subsidiary in Morocco to handle the distribution. As demand for the gadgets develops, marketing facilities are constructed or acquired, and ultimately the American concern may be impelled, by the impracticability of competing with local concerns on the basis of imported products, to install local manufacturing facilities. Even in this final development the local business contributes to the foreign commerce of the United States in that usually materials, and almost certainly manufacturing machinery, will be obtained from the United States; and, while the development of the business, the employment of local personnel and the availability for local consumption of the articles manufactured are beneficial to the country in which the business is conducted, the profits from the business, as well as the salaries paid to American personnel, enhance the national purchasing power of the United States. Irrespective of tariff barriers, if the operation of these businesses abroad became impossible by reason of local restrictions or discriminations, the foreign trade between the United States and these foreign countries would be seriously affected.

Thus the United States has a tremendous stake in maintaining the integrity of these substantial investments of American concerns, not only by reason of their intrinsic value, but also by reason of their importance in furthering international trade. While it is important to the maintenance of these businesses to obtain moderate and non-discriminatory customs duties on the products and materials imported from the United States into the foreign countries in which they operate, it is equally and sometimes more important that these American concerns should be secure in their investments abroad and free within these foreign countries from discriminatory taxes and burdensome restrictions of other characters.

In the second place, prior to the commencement of World War II there had developed throughout the world nationalistic policies in many countries aiming, in the case of some of our World War II enemies, at the economic and political conquest of other nations and, in the case of other countries, at self-sufficiency frequently invoked as a defensive measure against the economic activities of others. These poli-

${ }^{30}$ Economic Series No. 20 (U. S. Bur. of For. \& Dom. Comm., "American Direct Investments in Foreign Countries-r940") 4 .

s1 Id. at 5 . 
cies were implemented by government control over industry, by discriminatory measures against foreigners in local business, by subsidies, by foreign exchange control, by quantitative restrictions on imports and exports, and sometimes by monopolies created for the importation and exportation of commodities or by governmentcontrolled companies which competed with private enterprises engaged in the same fields of industry. Through these implements the government of one country would bargain bilaterally with another for preferential position in trade, with resulting discriminations against other countries.

Throughout most parts of the world there was increased participation in international commerce by governments. Associations with many of the characteristics of cartels were organized at the suggestion of or under compulsion from governments. Similar associations previously created by private interests came under governmental regulation and sponsorship and were turned into weapons of economic warfare. Among the major nations of the world, probably the United States alone did not participate in an important way in this development. The few commodity agreements to which the United States was a party before I94I represent the major deviations from its foreign economic policy of fostering private enterprise in international trade free of government control or participation. In the critical period before Pearl Harbor, these few exceptions modify only slightly the contrast between the policy of the United States and that of most foreign countries with an important position in international trade.

Thus World War II broke upon a world where, except in the United States, governmental controls over business were the rule rather than the exception and where government participation in business had become a not infrequent phenomenon. The commercial treaties of the United States had been created in a period when free enterprise was the rule and monopoly substantially an untried experiment, many treaties having been drafted when corporations were still too novel an institution to be mentioned and when the devices which were to become the principal weapons of economic nationalism had still to be invented.

In the United States as well as abroad, the war brought impetus to the trend toward government control over and participation in international business. Export licenses, export price control and the Trading-with-the-Enemy regulations were imposed in the United States in the small area of foreign commerce which remained in private hands. Lend-Lease and government operation of the American merchant marine represented the principal direct activities of the United States Government in foreign trade (exclusive of those incidental to our military operations abroad), while numerous government corporations such as Rubber Reserve Company and United States Commercial Company sent their representatives abroad to acquire supplies of critical materials needed here or to preempt similar materials needed by the enemy. Practically no transaction in foreign trade could be consummated in any country without governmental intervention. 


\section{Recent TRENDS}

During the war (1942-1945), the 1936 Treaty with France for the Avoidance of Double Taxation was revised effective $1945 .{ }^{32}$ A similar treaty with Great Britain has also been negotiated but has not yet been ratified by the United States Senate. ${ }^{33}$ Substantial progress was made in obtaining international agreements relative to aviation and, with the extension of the Reciprocal Trade Agreements Act. agreements under its provisions were entered into with Peru (1942), ${ }^{34}$ Iceland (1943), ${ }^{36}$ Mexico (1943), ${ }^{36}$ Uruguay (1943) ${ }^{37}$ and Iran (1944).$^{38}$ On the other hand, during the war no treaties of friendship, commerce and navigation were entered into nor, except as stated above, other comprehensive types of agreements providing protection for American nationals against restrictions and discriminations imposed by foreign countries. During this period hopes for a better post-war international world centered on the United Nations Organization and, within the sphere of trade and finance, on the Organization's Economic and Social Council and various multilateral organizations expected to be operated under the latter's auspices. These include the Food and Agricultural Organization, the International Civil Aviation Organization, the International Monetary Fund, the International Bank for Reconstruction and Development, and the International Trade Organization hereinabove referred to. The Anglo-American Petroleum Agreement, ${ }^{39}$ constituting a consultative pact between Great Britain and the United States as a preliminary to the calling of a conference of all interested nations to discuss a multilateral agreement along the same general lines, is expected to fall into this framework.

In 1937 the United States had entered into a five-year compact designed to regularize the production and marketing of sugar. ${ }^{40}$ It was signed by twenty-two nations. It had two broad objectives, establishing export quotas for producing countries and creating a council sitting permanently to study questions relating to sugar. In I940 a somewhat similar commodity agreement was entered into in regard to coffee, ${ }^{41}$ and in 1942 the wheat agreement became effective. ${ }^{42}$ These agreements constitute efforts by governments to deal with international trade in raw materials of which there exists or threatens a burdensome world surplus. The National Foreign Trade Convention has declared such agreements to be admissible "only in time of war or other international emergency or where considerations of national policy in the political or economic sphere outweigh the advantages of private trade and the

${ }^{22}$ Treaty Series 988. Sess.

${ }^{33}$ Transmitted by the President to the Senate April 24, 1945, Scnate Exccutive D, 79th Cong. Ist

${ }^{34}$ Executive Agreement Series 256.

${ }^{35}$ Executive Agreement Series 342.

${ }^{30}$ Executive Agreement Series 3 II.

${ }^{37}$ Executive Agreement Series 276.

${ }^{38} 58$ Star. (pt. 2) 1322, Executive Agreement Series 4 Io.

${ }^{30}$ Senate Executive E, 78 th Cong. 2d Sess. (1944). At date of writing, not yet ratified by the United States Senate.

${ }^{40}$ Senate Executive T, 75th Cong. Ist Sess. (1937), Treaty Series 990.

${ }^{4} 55$ Stat. (pt. 2) Ir 43, Treaty Series 970.

12 Executive Agreement Series 384 . 
freedom of the market place." ${ }^{33}$ The Proposals for Expansion of World Trade and Employment would restrict consideration of commodity agreements only to times when "measures for increasing the consumption of a commodity are unlikely to operate quickly enough to prevent excess supplies of the commodity from accumulating." ${ }^{44}$ It is also suggested in the Proposals that such agreements should not remain initially in effect for more than five years, and should be renewed only if substantial progress toward a solution of the underlying problem has been accomplished or if the renewed agreement is so revised as to be effective for this purpose.

Thus there have been official and unofficial pronouncements in the United States against undue use of commodity agreements for the orderly development of international trade. To the extent, however, that international trade is in the post-war world to be carried on by or under control of governments, the future importance of commodity agreements should not be minimized. A trend in the United States toward reversion to the free enterprise system would not necessarily free international trade from intervention by foreign governments. If foreign governments intervene it may be necessary for the United States Government to do likewise for the protection of the free enterprise system itself.

With the cessation of hostilities there has been some relaxation of controls over foreign trade by the United States but little, if any, comparable trend in foreign countries is as yet visible. Nationalization programs with incidental expropriation of American properties are in effect in eastern Europe and reported to be under consideration in countries of western Europe. In the areas liberated from enemy domination, the disproportion between the demand for imports and available means through exports or foreign exchange with which to pay for them-even should this country grant liberal credits-makes it appear unlikely that these areas can soon relinquish their control over imports, exports and foreign exchange transactions. The necessity for the early rehabilitation of destroyed industries on an efficient basis makes it appear likely that the governments in these liberated areas will continue to sponsor if not to participate in these industries. In other areas not so directly affected by the war, experiments have been initiated in various forms of partnerships between government and private business for the more rapid industrialization of the national economic life.

\section{Prospects for Modification of Restrictive Policies}

There seems no doubt but that the post-World-War-II period will prove to be one of conflict between two economic currents-one a continuation of the trend toward economic nationalism, which was a contributory cause of the war, and the other the trend first visible in the Reciprocal Trade Agreements program in the direction of international commerce on a multilateral basis. Since post-war international relationships are now taking form, it would seem that the United States, because of its important position in international trade, should promptly endeavor to. negotiate

\footnotetext{
${ }^{43}$ Nat'l For. Trade Council, op. cit. supra note 26 , in Principle XVII.
}

"DEP'T of STATE, op. cit. supra note $\mathrm{I}$, at 20. 
treaties establishing appropriate principles applicable to these relationships. Such action by the United States would not be inconsistent with the operation of the International Trade Organization as proposed. On the contrary, the establishment between two nations or among a limited group of nations of these principles might expedite their ultimate acceptance on a broad multilateral basis by all the members of the International Trade Organization.

The restrictive policies which we are considering are those of sovereign nations. Modification thereof can be obtained only ( $I$ ) by legislation of some super-national organization whose regulations will find compulsory acceptance, or (2) by the voluntary action of nations themselves, either unilaterally or through the adoption of multilateral or bilateral treaties or international agreements.

It seems unlikely that in the near future there will be any super-national organization which can dictate to the sovereign governments of the world as to the economic policies which they should follow. Neither the United Nations Organization nor the International Trade Organization as projected contemplates any such form of world government.

We believe it true that international trade on a multilateral basis and security for the investments of nationals of one country within the territory of another, with a minimum of governmental restrictions and discriminations, represent a sound longrange goal for each country from the point of view of its own welfare. Any step in that direction, however, is likely to cause short-range damage to particular interests or to run contrary to national prejudices. As stated in the Analysis of the Proposals for Expansion of World Trade and Employment, "Every country has its own kind of restrictions adapted to its own situation, and can hardly be expected to throw off its peculiar armor unless the other kinds of armor, employed by other countries, are thrown off at the same time."4J Whether many nations acting alone will make much progress toward the goal of unrestricted trade may be doubted. At the present time there is no indication of any voluntary trend in that direction. Progress toward the elimination of restrictions and discriminations as a result of the operation of the International Trade Organization cannot be expected to be immediate.

In the United States, restrictions and discriminations on foreign nationals and their business activities other than customs duties and import restrictions exist under various Federal and State laws, but in the aggregate they are of negligible significance; customs duties remain the principal burden imposed by the United States on foreign trade; therefore, in negotiating with the United States foreign countries are less interested in obtaining treaties of friendship, commerce and navigation than they are in securing reduced customs duties through negotiation of reciprocal trade agreements. On the other hand, in the case of many foreign countries, the reduction of customs duties is of less importance to American foreign trade than relief from other restrictions and discriminations imposed on American nationals. It follows

\footnotetext{
${ }^{25} I d$. at 3.
} 
that foreign countries are receptive to an invitation from the United States to negotiate reciprocal trade agreements, and one would expect the United States in many cases to press for the adoption of treaties of friendship, commerce and navigation. It would seem that the bargaining power of the United States, largely based on its control over American customs duties, may properly be used not only to secure from foreign countries reciprocal reductions in customs duties, as provided in reciprocal trade agreements, but also relief from restrictions and discriminations which fall outside of the scope of these agreements and are within the scope of other types of international agreements, including treaties of friendship, commerce and navigation.

If Country A, for example, imposes or threatens to impose burdensome restrictions on American concerns distributing American products in its territory by limiting unduly their right to employ American personnel or by discriminating against them in relation to internal taxation, an effort on the part of the United States to obtain a treaty to protect American concerns from such restrictions may be indicated. If, in a previously executed reciprocal trade agreement, the United States has exhausted its ability on a sound basis to reduce import duties on products imported from Country $A$, the negotiation of a treaty dealing with these restrictions may prove difficult. Country $A$ is likely to take little if any interest in obtaining for its nationals in the United States reciprocal protection against those types of restrictions which it is important for American nationals to secure in Country A. If, however, the United States is in a position to propose simultaneous negotiation of a reciprocal trade agreement and of those other types of treaties or agreements which are important to American nationals, the desire of Country $A$ to secure tariff benefits in the reciprocal trade agreement might ensure success for the entire program.

The discussions in the Autumn of 1945 dealing with the proposed credit to Great Britain constitute an outstanding example of negotiations which took into account all of the more important potential barriers to international trade for which either country might be responsible and which, from our point of view, were intended to create a congenial climate for international trade more rapidly than would be possible by the multilateral arrangements contemplated in the United Nations Organization. In presenting to Congress the financial agreement covering the British loan, President Truman stated, "Its most important purpose from our point of view is to cause the removal of emergency controls exercised by the United Kingdom over its international transactions far more speedily than is required by the Bretton Woods Agreements."46

\section{Conclusions}

Protection for American nationals in international trade in regard to those matters dealt with in treaties of friendship, commerce and navigation is substantially inadequate due to the large number of countries with which we have no such treaties and due to the many years which have elapsed and the great changes in

\footnotetext{
"' Message to Congress, January 30, 1946, reported in (Feb. 10, 1946) 14 Dep'T of StaTE BuLL. 183,184 .
} 
international trade which have occurred since a large proportion of existing treaties were drafted. With high rates of income taxation prevailing throughout the world, treaties for the avoidance of double taxation to protect against discriminatory and double taxation are of great importance. There are only four foreign countries with which the United States has comprehensive treaties of this type. Conventions for the protection of industrial property are likewise an essential part of our treaty system. The prompt negotiation of these various types of international agreements, as well as reciprocal trade agreements, is consistent with and should facilitate the functioning of the International Trade Organization.

In the prompt negotiation of reciprocal trade agreements which will reduce customs duties on products imported into the United States, this country will be taking an important step toward the reduction of barriers imposed by it upon international trade. In the case of many of the foreign countries with which these agreements are to be made, it is quite possible that for American nationals engaged in foreign trade the elimination of discriminations and restrictions of types not dealt with in reciprocal trade agreements is more important than the subjects therein dealt with. The negotiation of reciprocal trade agreements without contemporaneous consideration of commercial treaties and agreements of other types, such as treaties of friendship, commerce and navigation, treaties for the avoidance of double taxation, and treaties or conventions for the protection of industrial property, may involve the failure on the part of the United States to utilize important bargaining power derived from its ability, by the reduction of duties, to give products imported from foreign countries more adequate access to the American market.

The most effective approach toward the development and modernization of our commercial treaty system would seem to require, in the case of any particular foreign country, consideration of all matters in regard to which treaty protection was deemed desirable and the contemporaneous negotiation of all the various types of agreements necessary to cover these matters.

Whether and to what extent international commerce in the post-war world will be returned to private enterprise free of undue governmental intervention is still uncertain. A constructive and forceful treaty program by the United States could do much to determine the future character of commercial relations between nations. 